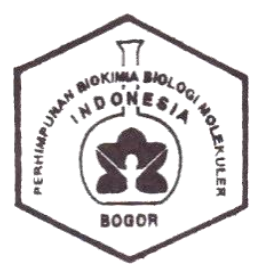

CURRENT BIOCHEMISTRY

ISSN: $2355-7877$

e-ISSN: 2355-7931

Journal homepage: http://journal.ipb.ac.id/index.php/cbj

Journal E-mail: current.biochemistry@gmail.com

\title{
Toxicity Test of Roots, Stems and Leaves of Citronella Lemongrass (Cymbopogon nardus)
}

(Uji Toksisitas Akar, Batang, dan Daun Tanaman Sereh Wangi (Cymbopogon nardus))

\author{
Waras Nurcholis ${ }^{1}{ }^{*}$, Mustika Weni $^{1}$, Rizki Fitria ${ }^{1}$, Najmah $^{1}$, Kornelia Rosvita Manek $^{1}$, B.Y. Habibi ${ }^{1}$ \\ ${ }^{1}$ Departemen Biokimia, IPB University, Bogor, 16680, Indonesia
}

Received: 6 January 2018; Accepted: 17 December 2019

Corresponding author : Waras Nurcholis, Departemen Biokimia, Fakultas Matematika dan Ilmu Pengetahuan Alam, IPB University; Email: wnurcholis@apps.ipb.ac.id

\begin{abstract}
Citronella lemongrass traditionally can be used as a mixture of waterbath for rheumatic patients, antiseptic medicine, headache reducer, to release the leech bite and overcome insect bite, but, the bioactivity potential of citronella lemongrass is still unknown. The content of citronella lemongrass is known to have secondary metabolites such as flavanoid, phenolic and terpenoid. The aim of this study was to determine $L C_{50}$ value (Letality Concentration 50) of the extracts of root, stem and leaves part of citronella lemongrass. Citronella lemongrass was extracted with maseration method using $96 \%$ ethanol solvent. The yield of leaf extract was higher than the yield of stem and root extract, which was $8.69 \%$ for stem extract, $3.73 \%$ for root extract and $9.70 \%$ for leaves extract. Toxicity test was performed by using Brine Shrimp Lethality Test (BSLT) method, shrimp larvae were put into the test solution with each different solution concentration. $L_{50}$ values were obtained based on calculation of percent mortality of shrimp larvae by using probit analysis. $L C_{50}$ ethanol extract $96 \%$ of citronella lemongrass leaf was $67.841 \mu \mathrm{g} / \mathrm{ml}$, citronella lemongrass stem was $31.604 \mu \mathrm{g} / \mathrm{ml}$ and citronella lemongrass root was $10.489 \mu \mathrm{g} / \mathrm{ml}$. LC $C_{50}$ value shows that $96 \%$ ethanol extract of root, stem and leaf of citronella lemongrass have no bioactivity potential indicated by the value of $L C_{50}$ which is higher than $1000 \mu \mathrm{g} / \mathrm{ml}$.
\end{abstract}

Keywords: Cymbopogon nardus, $L C_{50}$, BSLT, Sitotoxicity

\begin{abstract}
ABSTRAK
Sereh wangi secara tradisional dapat digunakan sebagai campuran air mandi untuk penderita rematik, obat antiseptik, meredakan sakit kepala, melepaskan gigitan lintah dan mengatasi gigitan serangga, namun potensi bioaktivitas sereh wangi belum banyak diketahui. Kandungan sereh wangi diketahui memiliki metabolit sekunder seperti flavanoid, fenolik dan terpenoid. Tujuan penelitian ini menentukan nilai $L C_{50}$ (Letality Concentration 50) dari ekstrak bagian akar, batang dan daun tanaman sereh wangi. Sereh wangi diekstrak dengan metode
\end{abstract}


maserasi menggunakan pelarut etanol 96\%. Nilai rendemen ekstrak daun lebih tinggi dibandingkan dengan ekstrak batang dan akar, yaitu sebesar 8.69\% untuk ekstrak batang, $3.73 \%$ untuk ekstrak akar dan $9.70 \%$ untuk ekstrak daun. Uji toksisitas dilakukan dengan menggunakan metode BSLT, larva udang dimasukkan ke dalam larutan uji dengan masing-masing konsentrasi larutan yang berbeda. Nilai $L C_{50}$ diperoleh berdasarkan perhitungan persen kematian larva udang menggunakan analisis probit. Hasil LC $C_{50}$ ekstrak etanol $96 \%$ dari daun sereh wangi sebesar 67.841 $\mu \mathrm{g} / \mathrm{ml}$, batang sereh wangi sebesar $31.604 \mu \mathrm{g} / \mathrm{ml}$ dan akar sereh wangi sebesar $10.489 \mu \mathrm{g} / \mathrm{ml}$. Nilai $L C_{50}$ menunjukkan ekstrak etanol $96 \%$ akar, batang dan daun sereh wangi tidak memiliki potensi bioaktivitas karena nilai $L_{50}$ lebih tinggi dari $1000 \mu \mathrm{g} / \mathrm{ml}$.

Keywords: Cymbopogon nardus, $L C_{50}, B S L T$, Sitotoksisitas

\section{PENDAHULUAN}

Tumbuhan merupakan salah satu bahan obat tradisional yang telah dikenal sejak dahulu kala. Dalam dasawarsa terakhir ini penggunaan obat tradisional telah menarik perhatian dan kepopulerannya di masyarakat semakin meningkat. Salah satu penyebabnya adalah penerimaan masyarakat terhadap manfaat dan kegunaan tumbuhan obat dalam pemeliharaan kesehatan (Frengki 2014). Suatu tumbuhan dapat digunakan sebagai sumber obat baru karena memiliki kandungan senyawa metabolit sekunder. Salah satu tanaman yang digunakan sebagai obat tradisional adalah sereh wangi (Cymbopogon winterianus Jowitt) yang memiliki kandungan senyawa aktif seperti saponin, flavonoid, polifenol, alkaloid dan minyak atsiri (Puspawati et al. 2016).

Sereh wangi (Cymbopogon nardus) sangat bermanfaat dalam kesehatan. Tanaman sereh bermanfaat untuk anti radang, anti nyamuk, menghilangkan rasa sakit dan melancarkan sirkulasi darah. Manfaat lain dari tanaman sereh untuk sakit kepala, otot, batuk, nyeri lambung, haid tidak teratur dan bengkak setelah melahirkan. Akar tanaman sereh digunakan sebagai peluruh air seni, peluruh keringat, peluruh dahak, bahan untuk kumur dan penghangat badan sedangkan daun sereh digunakan sebagai peluruh angin perut, penambah nafsu makan, pengobatan pasca persalinan, penurun panas dan pereda kejang (Dewi et al. 2012).

Lazimnya setiap penelitian bahan alam yang diduga berpotensi sebagai obat maupun secara empiris telah digunakan masyarakat sebagai obat, diawali dengan uji pre-klinis toksisitas untuk memprediksi tingkat keamanannya. Metode uji toksisitas dapat dilakukan secara in vitro maupun in vivo. Salah satu metode toksisitas in vitro yang sering digunakan adalah metode Brine Shrimp Letality Test (BSLT). Metode BSLT merupakan salah satu cara yang cepat dan murah untuk skrining toksisitas dari ekstrak tanaman dengan menggunakan hewan laut yaitu larva udang Artemia salina Leach. Uji toksisitas dengan metode BSLT ini memiliki spektrum aktivitas farmakologi yang luas, prosedurnya sederhana, cepat dan tidak membutuhkan biaya yang besar, serta hasilnya dapat dipercaya. Di samping itu, metode ini sering dikaitkan dengan metode penapisan senyawa antikanker. Dengan alasan-alasan tersebut, maka uji ini sangat tepat digunakan dalam mengawali penelitian bahan alam (Frengki 2014). Penelitian ini bertujuan menganalisis potensi bioaktivitas tanaman sereh wangi menggunakan metode Brine Shrimp Letality Test (BSLT).

\section{METODOLOGI}

Alat yang digunakan untuk preparasi sampel dan analisis kadar air pada sampel sereh wangi (akar, batang dan daun) yaitu gunting stainless steel, pisau, loyang, oven Eyela NDO- 700, desikator, neraca analitik Ohaus GA200, cawan porselin dan blender. Alat yang digunakan untuk ekstraksi sampel adalah Erlenmeyer, shaker orbital, gelas ukur, 
neraca analitik Ohaus GA200, dan rotary evaporator Eyela. Alat yang digunakan untuk uji toksisitas adalah pelat BSLT dan pipet mikro Hirschmann.

Bahan-bahan yang digunakan untuk preparasi sampel dan kadar air adalah sampel sereh wangi (akar, batang, daun) yang telah dibersihkan dan simplisia. Bahan yang digunakan untuk ekstraksi sampel adalah simplisia dan etanol absolut $96 \%$. Bahanbahan yang digunakan untuk uji toksisitas adalah air laut, ekstrak sereh wangi dan larva udang Artemia salina Leach.

\section{Preparasi Sampel}

Sampel tanaman sereh wangi (akar, batang dan daun) yang digunakan diperoleh dari taman koleksi biofarmaka IPB di daerah Cikabayan, Gunung Asten, Banten, Ciampea, Bogor, Jawa Barat. Diambil pada ketinggian $142.42 \mathrm{~m}$ di atas permukaan laut dengan posisi garis lintang: -6.5470, dan garis bujur: 106.71671. Masing-masing sampel akar, batang dan daun sereh wangi diambil dicuci bersih dan dikeringanginkan pada suhu kamar untuk menghilangkan air. Setelah itu, sampel yang telah kering dipotong kecil-kecil menggunakan gunting atau pisau. Setelah itu, ditimbang bobot sampel dan dikeringkan dalam oven dengan suhu $105{ }^{\circ} \mathrm{C}$ selama 72-96 jam. Kemudian sampel yang telah kering, dihaluskan dengan menggunakan blender sampai menjadi serbuk (simplisia) berukuran 100 mesh.

\section{Analisis Kadar Air (AOAC 2005) dan Rendemen}

Analisis kadar air dilakukan sebanyak tiga kali ulangan pada masingmasing simplisia akar, batang, dan daun sereh wangi. Cawan porselen dikeringkan selama 15 menit dalam oven pada suhu $105^{\circ} \mathrm{C}$, kemudian dimasukkan dalam desikator selama 10 menit. Selanjutnya, cawan porselen ditimbang hingga berat konstan sebagai berat awal. Setelah diperoleh berat konstan, ditimbang simplisia sebanyak 2 gram ke dalam cawan porselen, setelah itu dimasukkan ke dalam oven pada suhu $105{ }^{\circ} \mathrm{C}$ selama 3 jam. Kemudian dimasukkan lagi cawan tersebut ke dalam desikator selama 10 menit dan selanjutnya ditimbang beratnya. Prosedur ini dilakukan hingga diperoleh berat konstan. Perhitungan kadar air dapat menggunakan rumus sebagai berikut.

Kadar $\operatorname{air}(\%)=\frac{B-(A-C)}{B} \times 100 \%$

Keterangan :

$\mathrm{A}=$ Berat cawan dan simplisia (gram)

$\mathrm{B}=$ Berat sampel awal (gram)

$\mathrm{C}=$ Berat cawan kosong (gram)

Untuk perhitungan rendemen rumusnya sebagai berikut:

Rendemen (\%)

$$
=\frac{\text { Berat ekstrak }}{\text { Berat simplisia sebelum ekstrak }} \times 100 \%
$$

\section{Ekstraksi Sereh Wangi (Akar, Batang, dan Daun)}

Ekstraksi sereh wangi dilakukan dengan metode maserasi menggunakan pelarut etanol $96 \%$. Masing-masing simplisia ditimbang sebanyak 30 gram, kemudian dimasukkan dalam Erlenmeyer. Selanjutnya larutan etanol $96 \%$ dimasukkan ke dalam Erlenmeyer yang telah berisi simplisia dengan perbandingan 1 : 10. Setelah itu dishaker selama 24 jam dalam suhu kamar dengan kecepatan $150 \mathrm{rpm}$. Setelah dishaker, pelarut dipisah dari simplisia dengan menggunakan kertas saring dan filtrasi dilakukan sebanyak 2 kali. Selanjutnya untuk memperoleh ekstrak berupa padatan (pasta) maka dilakukan evaporasi menggunakan rotary evaporator pada suhu $50{ }^{\circ} \mathrm{C}$. Filtrat yang diperoleh kemudian disimpan untuk dilakukan pengujian selanjutnya.

Uji Toksisitas dengan Brine Shrimp

Lethality Test (BSLT) (Meyer et al. 1982)

Penumbuhan Larva Udang 
Pada masing-masing ekstrak sereh wanggi (akar, batang dan daun) dilakukan penumbuhaan larva udang Artemia salina Leach. yang dimasukan ke dalam toples yang telah ditambahkan air laut. Larva udang diinkubasi selama 24 jam dan dimasukkan juga aerator ke dalam toples.

\section{Pembuatan Larutan Stok Uji.}

Larutan stok uji dibuat 10000 ppm dengan berat sampel 0.25 gram dilarutkan dengan air laut. Dilakukan pengenceran larutan stok uji 10.000 ppm menjadi 500, 750, 1000, 1250, 2500 dan 5000 ppm.

\section{Uji BSLT}

Sebanyak 10 ekor larva udang yang telah diinkubasi selama 24 jam dimasukkan ke dalam plat uji yang telah ditambahkan $1 \mathrm{ml}$ air laut dan $0.5 \mathrm{ml}$ ekstrak sereh wangi dengan masing-masing konsentrasi 500, 750, 1000, 1250, 2500, 5000 ppm. Kemudian plat uji ditera dengan air laut sampai $5 \mathrm{ml}$. Selanjutnya untuk menghitung $\mathrm{LC}_{50}$, larva udang diinkubasi selama 24 jam, selanjutnya diamati dan dihitung larva udang yang mati. Nilai $\mathrm{LC}_{50}$ dapat ditentukan dengan analisis probit menggunakan program SPSS 22.0.

\section{HASIL}

\section{Kadar Air dan Rendemen Ekstrak Daun Sereh Wangi}

Kadar air diperoleh dari perbandingan penurunan bobot sampel dengan bobot simplisia yang digunakan. Kadar air ekstrak etanol 96\% masing-masing bagian sereh wangi (akar, batang dan daun) digunakan untuk mengoreksi hasil rendemen ekstrak yang didapat. Kadar air rata-rata simplisia daun sebesar $0.02 \%$, batang sebesar $2.42 \%$ dan akar sebesar $5.60 \%$.

Rendemen ekstrak merupakan senyawa bioaktif yang diperoleh berdasarkan pelarut yang digunakan. Rendemen ekstrak didapat dari perbandingan bobot ekstrak dengan bobot simplisia. Hasil rendemen ekstrak dapat dilihat pada Tabel 2. Berdasarkan hasil yang diperoleh, rendemen ekstrak daun lebih tinggi dibandingkan dengan ekstrak batang dan akar, sebesar 9.70\%. Rendemen ekstrak akar sebesar $3.73 \%$, sedangkan rendemen ekstrak batang sebesar $8.69 \%$. Hal tersebut menunjukkan bahwa senyawa bioaktif yang terkandung di dalam simplisia ekstrak etanol $96 \%$ batang sereh wangi lebih banyak terekstrak dibanding ekstrak etanol $96 \%$ pada bagian akar dan daun.

\section{Sitotoksisitas ekstrak akar, batang, dan daun sereh wangi}

Sitotoksisitas ekstrak akar, batang, dan daun sereh wangi ditetapkan dalam $\mathrm{LC}_{50}$ dengan metode BSLT. Nilai LC $_{50}$ diperoleh melalui analisis probit dengan program SPSS 22. Nilai $\mathrm{LC}_{50}$ menunjukkan sitotoksisitas ekstrak etanol 96\% akar, batang dan daun sereh wangi (Tabel 3). Hasil uji BSLT menunjukkan $\mathrm{LC}_{50}$ esktrak etanol $96 \%$ daun lebih tinggi dibandingkan dengan sampel yang lain sebesar $67.841 \mu \mathrm{g} / \mathrm{mL}$. Nilai LC $_{50}$ ekstrak etanol $96 \%$ batang sebesar $31.604 \mu \mathrm{g} / \mathrm{mL}$, dan ekstrak etanol 96\% akar merupakan nilai terkecil yaitu $10.489 \mu \mathrm{g} / \mathrm{mL}$.

Tabel 1 Persen Kadar Air Sampel

\begin{tabular}{ll}
\hline Sampel Ekstrak etanol $96 \%$ & Kadar Air (\%) \\
\hline Akar & $5.60 \%$ \\
Batang & $2.42 \%$ \\
Daun & $0.02 \%$ \\
\hline
\end{tabular}




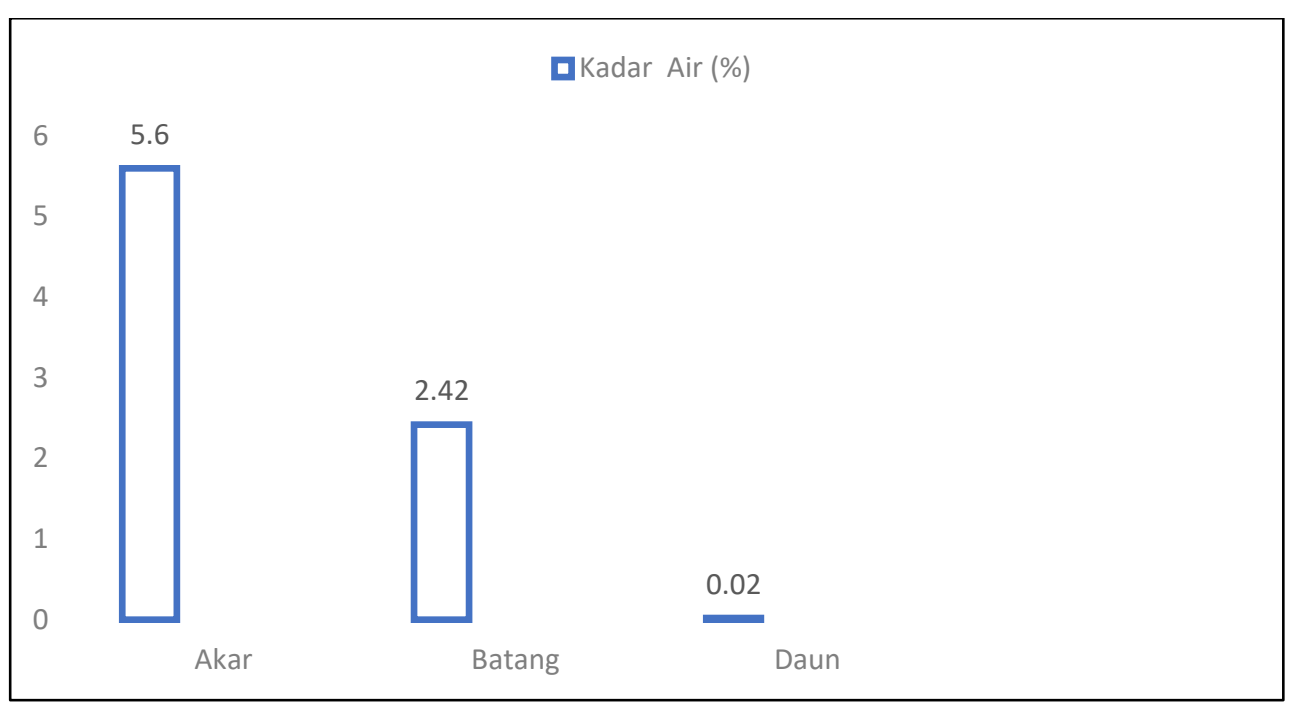

Gambar 1 Grafik persen kadar air sampel

Tabel 2 Persen rendemen sampel

\begin{tabular}{ll}
\hline Sampel Ekstrak etanol $96 \%$ & Rendemen Ekstrak \\
\hline Akar & $3.73 \%$ \\
Batang & $8.69 \%$ \\
Daun & $9.70 \%$ \\
\hline
\end{tabular}

Tabel 3 Sitotoksisitas ekstrak akar, batang dan daun sereh wangi

\begin{tabular}{ll}
\hline Sampel & $\mathrm{LC}_{50}(\mu \mathrm{g} / \mathrm{mL})$ \\
\hline Akar & 10.489 \\
Batang & 31.604 \\
Daun & 67.841 \\
\hline
\end{tabular}

\section{PEMBAHASAN}

Mutu bahan baku memegang peranan yang cukup penting, karena setiap bahan baku akan memberikan kandungan dan komposisi senyawa aktif yang sangat spesifik (Trisnamurti dan Basuki 2005). Penelitian ini bertujuan untuk menetapkan parameter standardisasi non spesifik dan spesifik dari ekstrak etanol $96 \%$ daun sereh wangi (Cymbopogon nardus L.) sehingga kedepannya dapat memberikan informasi ilmiah dari Cymbopogon nardus L. Parameter non spesifik lebih terkait dengan faktor lingkungan dari pembuatan ekstrak. Air termasuk salah satu indikator kualitas suatu simplisia tanaman obat dan bahan pangan. Air yang terdapat dalam simplisia dapat memengaruhi daya tahan terhadap serangan mikrob. Jumlah air bebas yang digunakan mikrob untuk pertumbuhannya disebut aw (water activity). Nilai aw setiap mikrob berbeda beda, seperti bakteri memiliki aw 0.90. Oleh karena itu, simplisia harus mengalami pengeringan terlebih dahulu untuk mengurangi kadar air yang terdapat didalamnya (Winarno 2008). Kadar air dinyatakan sebagai persentase perbandingan berat air bebas yang terikat pada membran matriks dengan air yang menguap akibat pengeringan. 
Pengeringan sampel bertujuan mengurangi kandungan air agar dapat memperpanjang masa simpan suatu bahan. Kandungan air yang terlalu tinggi dapat menyebabkan terjadinya reaksi enzimatik. Reaksi enzimatik dapat menyebabkan perubahan kimia dalam simplisia (Ma'mun et al 2006). Kadar air dalam ekstrak etanol $96 \%$ daun sereh wangi (Cymbopogon nardus L.) diperoleh sebesar 5.6\%. Menurut literatur range kadar air yang diperbolehkan untuk jenis ekstrak kental adalah antara 5-30\%. Sementara untuk ekstrak cair adalah lebih besar dari 30\% dan ekstrak kering lebih kecil dari 5\%. Penentuan kadar air juga terkait dengan kemurnian ekstrak. Semakin sedikit kadar air pada ekstrak maka semakin sedikit kemungkinan ekstrak terkontaminasi oleh pertumbuhan jamur (Saifudin et al 2011).

$$
\text { Rendemen ekstrak merupakan }
$$

presentase perbandingan berat ekstrak dengan berat simplisia. Rendemen ekstrak diperoleh dengan mengekstraksi simplisia daun sereh wangi. Metode ekstraksi yang digunakan adalah maserasi dengan etanol 96\%. Metode maserasi dilakukan dengan cara merendam simplisia dengan pelarut dalam waktu dan suhu tertentu. Pemilihan pelarut air dan etanol didasarkan pada peraturan BPOM (2010) yang menyatakan bahwa hanya air dan etanol yang diizinkan untuk keperluan farmakologi. Penentuan rendemen pada ekstrak etanol 96\% daun sereh wangi (Cymbopogon nardus L.) berfungsi untuk mengetahui kadar metabolit sekunder yang terbawa oleh pelarut, namun tidak dapat menentukan jenis senyawanya (Ukieyanna 2012). Selain dipengaruhi pelarut, rendemen juga dipengaruhi oleh kadar air yang ada pada suatu bahan. Ekstraksi yang dilakukan pada bahan kering menghasilkan rendemen lebih banyak dibandingkan bahan yang segar. Hal itu disebabkan adanya sel yang mengalami kerusakan atau pecah dan kandungan airnya sangat rendah, sehingga ekstraksi dengan pelarut organik menjadi mudah dan memberikan hasil rendemen yang banyak (Drastinawati 2005).
Sereh wangi banyak terdapat di Indonesia dan digunakan oleh masyarakat sebagai obat-obatan tradisional karena mengandung berbagai senyawa kimia. Untuk tanaman yang digunakan sebagai obat-obatan, perlu dilakukan uji untuk mengetahui tingkat toksisitas dari tanaman tersebut. Untuk mengetahui toksisitas tanaman sereh wangi, digunakan metode BSLT (Brine Shrimp Lethality Test) dengan tiga kali pengulangan. Daur hidup pertumbuhan Artemia salina terdiri dari tiga tahap, yaitu kista, napuli dan dewasa. Tahap napuli adalah tahap yang digunakan sebagai larva uji toksisitas dengan metode BSLT. Uji toksisitas menggunakan larva udang Artemia Salina Leach dilakukan karena memiliki beberapa keunggulan diantaranya hasil dapat dipercaya, memiliki spektrum aktivitas farmakologi yang luas, mudah dilakukan dan murah (Meyer et al 1982). Didalam masing-masing wadah uji diletakkan $1 \mathrm{~mL}$ air laut kemudian dimasukkan 10 ekor larva udang, kemudian di tambahkan ekstrak dari bagian akar, batang dan daun tanaman sereh wangi masing-masing $0.5 \mathrm{~mL}$ kemudian ditambahkan air laut kembali hingga $5 \mathrm{~mL}$. Konsentrasi dari masing-masing ekstrak etanol akar, batang dan daun yang digunakan sebesar 50, 100, 500 dan 1000 ppm dengan kontrol berupa larva udang tanpa tambahan ekstrak etanol tanaman sereh wangi. Larutan dibiarkan selama 24 jam kemudian dihitung berapa ekor larva udang yang mati dari tiap wadah uji. Selanjutnya dihitung mortalitas dengan menghitung Lethal Concentration $\left(\mathrm{LC}_{50}\right)$ yang merupakan konsentrasi dimana suatu zat dapat menyebabkan kematian 50\% Artemia salina. Struktur anatomi tubuh Artemia salina pada tahap napuli masih sangat sederhana. Perubahan konsentrasi yang drastis antara dalam dan luar sel dapat menyebabkan senyawa toksik mampu menyebar merata ke tubuh Artemia salina dan menyebabkan kerusakan metabolisme yang cepat dan dapat terdeteksi dalam waktu 24 jam hingga 
menyebabkan 50\% kematian Artemia salina. Nilai $\mathrm{LC}_{50}$ didapat dengan memakai regresi linier probit yang dihitung menggunakan IBM statistic 22. Hasil uji menunjukkan nilai $\mathrm{LC}_{50}$ pada ekstrakakar sebesar $10.489 \mu \mathrm{g} / \mathrm{mL}$, ekstrak batang sebesar $31.604 \mu \mathrm{g} / \mathrm{mL}$ dan ekstrak daun sebesar $67.841 \mu \mathrm{g} / \mathrm{mL}$. Tingkat toksisitas suatu senyawa menjadi senyawa yang memiliki potensi bioaktivitas jika $\mathrm{LC}_{50}$ kurang dari $1000 \mu \mathrm{g} / \mathrm{mL}$ dan senyawa tidak memiliki potensi bioaktivitas jika $\mathrm{LC}_{50}$ lebih dari $1000 \mu \mathrm{g} / \mathrm{mL}$ (Anderson et al. 1991). Sehingga dapat disimpulkan bahwa ekstrak etanol dari akar, batang dan daun tanaman sereh wangi tidak memiliki potensi bioaktivitas karena nilai $\mathrm{LC}_{50}$ lebih besar dari $1000 \mu \mathrm{g} / \mathrm{mL}$.

Dari hasil penelitian didapat bahwa tingkat kematian larva udang berbeda pada setiap ekstrak bagian tanaman sereh wangi sehingga tingkat toksisitas nya juga berbeda. Tinggi rendahnya persentasi kematian larva udang berbanding terbalik dengan nilai $\mathrm{LC}_{50}$ nya. Semakin tinggi nilai $\mathrm{LC}_{50}$ maka semakin rendah tingkat kematian larva, dan sebaliknya. Namun, dari ketiga ekstrak etanol akar, batang dan daun tanaman sereh wangi didapat bahwa ketiga nya tidak memiliki potensi bioaktivitas karena nilai $\mathrm{LC}_{50}$ nya yang besar (lebih dari $1000 \mu \mathrm{g} / \mathrm{mL}$ ). Hendrik et al. (2013) menemukan bahwa sereh wangi mengandung beberapa senyawa metabolit sekunder seperti flavonoid, fenolik dan terpenoid dimana senyawa-seyawa tersebut merupakan senyawa metabolit sekunder yang tidak bersifat toksik. Lisdawati et al. (2006) menyatakan perbedaan kadar metabolit sekunder yang terekstraksi akan sebanding dengan tingkat toksisitasnya sehingga hal ini bisa menjadi salah satu penyebab ekstrak akar, batang dan daun dari sereh wangi tidak bersifat toksik karena senyawa-senyawa metabolit sekunder tersebut ikut terekstrak ke dalamnya.

Dari hasil penelitian didapat rendemen ekstrak akar sebesar 3.73\%, batang 8.69\% dan daun sereh wangi sebesar $9.70 \%$ sedangkan hasil analisis probit menunjukkan bahwa ekstrak akar, batang dan daun tidak memiliki potensi bioaktivitas karena nilai $\mathrm{LC}_{50}$ masingmasing ekstrak akar, batang dan daun tanaman sereh wangi lebih dari $1000 \mu \mathrm{g} / \mathrm{mL}$.

\section{DAFTAR PUSTAKA}

Anderson JE, Goetz CM, McLaughlin, JL, Suffness M. 1991. A Blind Comparison of Simple Bench-top Bioassays and Human Tumour Cell Cytotoxicities as Antitumor Prescreens. Phytochem Analysis (2): 107-111.

[BPOM] Badan Pengawas Obat dan Makanan. 2010. Acuan Sediaan Herbal. Volume 5 edisi 1. Jakarta (ID): Direktorat OAI BPOM RI.

Dewi LN, Nurhaini R, Handayani S. 2012. Formulasi Gel Antinyamuk Minyak Atsiri Batang Sereh Wangi (Cymbopogon nardus, L. Rendle). CERATA Journal of Pharmacy Science. 3 (1) : 7-18.

Drastinawati Y. 2005. Ekstraksi senyawa metabolit sekunder dari daun tanaman tutup bumi. Jurnal Sains dan Teknologi. 4:16-19

Frengki. 2014. Uji Toksisitas Ekstrak Etanol Sarang Semut Lokal Aceh (Mymercodia sp.) dengan Metode BSLT Terhadap Larva Udang Artemia salina Leach. Jurnal Medika Veterinaria 8(1)

Hendrik G, Willem E, Panggabean AS. 2013. Pemanfaatan Tumbuhan Serai Wangi (Cymbopogon nardus L) Sebagai Antioksidan Alami. Jurnal Kimia Mulawarman 10(2).

Lisdawati V, Wiryowidagdo S, Kardono LBS. 2006. Brine Shrimp Lethality Test (BSLT) dari berbagai fraksi ekstrak daging buah dan kulit biji mahkota dewa (Phaleria macrocarpa). Bul. Penel. Kesehatan. 34(3):111-118. 
Ma'mun, Suhirman S, Manoi F, Sembiring BS, Tritianingsih, Sukmasari M, Gani A, Tjitjah F, Kustiwa D. 2006. Teknik pembuatan siplisia dan ekstrak purwoceng [catatan penelitian]. 314-324.

Meyer BN, Ferrigni NR, Putnam JE, Jacobsen LB, Nichols DE, McLaughin JL. 1982. Brine shrimp: a convenient general bioassay for active plant constituent. Planta Medica. 45:31-34.

Puspitawati, NM. Isolasi, Identifikasi, serta Uji Aktivitas Antibakteri Pada Minyak Atsiri Sereh Wangi (Cymbopogon winterianus Jowitt) Jurnal Kimia 10 (2), Juli 2016: 219-227

Saifudin A, Rahayu V, Teruna HY. 2011. Standardisasi Bahan Obat Alam. Yogyakarta: Graha Ilmu.

Sinta MT, RH, Basuki T. 2005. Functional food industry: Trends and Challenges. LIPI Press, Jakarta : 59-77.

Winarno FG. 2008. Kimia Pangan. Jakarta (ID) : Gramedia Pustaka Utama. 